REPORTS AND INVESTIGATIONS BY THE GROUND WATER BRANCH, U.S. GEOLOGICAL SURVEY, IN CALIFORNIA SINCE 1940

(Status as of January 1962)

Northern California: Area North of San Francisco Bay

Map

no.

1 Back, William, 1957, Reconnaissance of geology and ground-water resources of Smith River plain, Del Norte County, Calif.: U.S. Geol. Survey Water-Supply Paper 1254, prepared in cooperation with the California Department of Water Resources, $76 \mathrm{p}$.

8 Cardwell, G. T., 1958, Geology and ground water in the Santa Rosa and Petaluma Valley areas, Sonoma County, Calif.: U.S. Geol. Survey Water-Supply Paper 1427, prepared in cooperation with the California Department of Water Resources, $273 \mathrm{p}$. 1961, Geology and ground water in Russian River valley areas and in Round, Laytonville, and Little Lake Valleys, Sonoma and Mendocino Counties, Calif.: U.S. Geol. Survey typewritten rept., prepared in cooperation with the California Department of Water Resources, 271 p. (in preparation as a water-supply paper).

11 Davis, G. H., and Olmsted, F. H., 1952, Geologic features and ground-water storage capacity of the Sutter-Yuba area, Calif.: California Water Resources Board Bull. 6, appendix B, p. 89-104.

5 Evenson, R. E., 1959, Reconnaissance of the geology and ground-water features of the Eureka area, Humboldt County, Calif.: U.S. Geol. Survey Water-Supply Paper 1470, prepared in cooperation with the California Department of Water Resources, (? p.

57 Hilton, G. S., 1961, Water-resources reconnals: nce in southeastern part of Honey Lake Valley, Lassen County, California: U.S. Geol. Survey typewritten rept., prepared in cooperation with U.S. Department of the Army, $16 \mathrm{p}$. (in preparation as a water-supply paper).

Kunkel, Fred, and Upson, J. E., 1960, Geology and ground water in Napa and Sonoma Valleys, Napa and Sonoma Countles, Calif.: U.S. Geol. Survey Water-Supply Paper 1495, prepared in cooperation with the California Department of Water Resources, $252 \mathrm{p}$.

Mack, Seymour, 1959, Geology and ground-water features of Scott Valley, Siskiyou County, Calif.: U.S. Geol. Survey Water-Supply Paper 1462, prepared in cooperation with the California Department of Water Resources, $98 \mathrm{p}$. 
3 Mack, Seymour, 1960, Geology and ground-water features of Shasta Valley, Siskiyou County, Calif.: U.S. Geol. Survey Water-Supply Paper 1484, prepared in cooperation with the California Department of Water Resources, $115 \mathrm{p}$.

Olmsted, F. H., 1956, Summary of ground-water conditions in northwestern California, in Natural resources of northwestern California, waterresources ap iendix: U.S. Dept. of Interior, Pacific Southwest Field Committee duplicated preliminary rept., p. 1-93.

Olmsted, F. H., and Davis, G. H., 1961, Geologic features and ground-water storage capacity of the Sacramento Valley, Calif.: U.S. Geol. Survey Water-Supply Paper 1497, prepared in cooperation with the California Department of Water Resources, $241 \mathrm{p}$.

Poole, J. L., 1960, Water-resources reconnaissance of Hoopa Valley, Humboldt County, California: U.S. Geol. Survey typewritten report, prepared at the request of the U.S. Bureau of Indian Affairs, $40 \mathrm{p}$. (in preparation as a water-supply paper).

Foland, J. F., Davis, G. H., Olmsted, F. H., and Kunkel, Fred, 1949, Ground-water storage capacity of the Sacramento Valley, Calif.: California State Water Resources Board Bull. no. 1, appendix D, p. 618-648. water resources, and usable ground-water storage capacity of part of Solano County, California: U.S. Geol. Survey Water-Supply Paper 1464, prepared in cooperation with the U.S. Bureau of Reclamation, 693 p.

7 Upson, J. E., and Kunkel, Fred, 1955, Ground water in the Lower LakeMiddletown area, Lake County, Calif.: U.S. Geol. Survey Water-Supply Paper 1297, prepared in cooperation with the California Department of Water Resources, $83 \mathrm{p}$.

4 Wood, P. R., 1960, Geology and ground-water features of the Butte Valley region, Siskiyou County, Calif.: U.S. Geol. Survey WaterSupply Faper 1491, prepared in cooperation with the California Department of Water Resources, $150 \mathrm{p}$.

Worts, G. F., Jr., and others, 1950, Progress report on the ground-water investigation in Solano County, Calif.: U.S. Geol. Survey dupl. rept., prepared in cooperation with the U.S. Bureau of Reclamation, $50 \mathrm{p}$. 
Central California: Area South of San Francisco Bay and North of Tehachapi Mountains

Map

no.

Davis, G. H., 1961, Geologic control of mineral composition of stream waters of the eastern slope of the southern Coast Ranges, California: U.S. Geol. Survey Water-Supply Paper 1535-B, $30 \mathrm{p}$.

14 Davis, G. H., and Poland, J. F., 1957, Ground-water conditions in the Mendota-Huron area, Fresno and Kings Counties, Calif.: U.S. Geol. Survey Water-Supply Paper 1360-G, prepared in cooperation with the California Department of Water Resources, p. 409-588.

13 Davis, G. H., Green, J. H., Olmsted, F. H., and Brown, D. W., 1959, Ground-water conditions and storage capacity in the San Joaquin Valley, Calif.: U.S. Geol. Survey Water-Supply Paper 1469, prepared in cooperation with the California Department of Water Resources, $287 \mathrm{p}$.

16 Davis, G. H., Lofgren, B. E., and Mack, Seymour, 1960, Use of ground-water reservoirs for storage of surface water in the San Joaquin Valley, California: U.S. Geol. Survey typewritten report. prepared in cooperation with the California Department of Water Resources, $292 \mathrm{p}$. (in preparation as a water-supply paper).

51 Evenson, R. E., 1960, Ground-water reconnaissance at Pinnacles National Monument, Calif.: U.S. Geol. Survey typewritten rept., prepared at the request of the National Park Service, 23 p. 'in preparation as a chapter in the water-supply paper series "Hydrology of the Public Domain").

13 Livingston, P. P., 1944, Ground-water features of the San Joaquin Valley, Calif.--A review of published and unpublished reports and papers: U.S. Geol. Survey duplicated report, $48 \mathrm{p}$.

15 Wood, P. R., and Davis, G. H., 1959, Ground-water conditions in the Avenal-McKittrick area, Kings and Kern Counties, Calif.: U.S. Geol. Survey Water-Supply Paper 1457, prepared in cooperation with the U.S. Bureau of Reclamation, $141 \mathrm{p}$.

18 Wood, P. R., and Dale, R. H., 1960, Geology and ground-water features of the Edison-Maricopa area, Kern County, California: U.S. Geol. Survey typewritten rept., prepared in cooperation with the California Department of Water Resources, 223 p. (in preparation as a watersupply paper).

19 Terra Bella-Lost Hills (formerly called Ducor-Famoso), San Joaquin Valley (report in preparation)

52 Kern River fan area (report in preparation)

61 Kaweah-Tule area (investigation in progress) 
17 Bull, W. B., 1961, Alluvial fans and near-surface subsidence, western Fresno County, California: U.S. Geol. Survey dupl. rept., prepared in cooperation with the California Department of Water Resources, 283 p., 72 figs. (in preparation as a USGS Professional Paper).

Green, J. H., 1955, Partial bibliography of land-surface subsidence: U.S. Geol. Survey dupl. rept., 28 p.

17 Green, J. H., and Cochran, W. A., 1958, Geology of the deposits of late Tertiary and Quaternary age along the west border of the San Joaquin Valley, Calif., from Los Banos to Kettleman City: U.S. Geol. Survey open-file map, scale 1:62,500.

17,20 Inter-Agency Cormittee on Land Subsidence in the San Joaquin Valley, 1958, Progress report on land-subsidence investigations in the San Joaquin Valley, California, through 1957: Duplicated rept., 160 p., 45 figs.

17 Lofgren, B. E., 1960, Near-surface land subsidence in western San Joaquin Valley: Am. Geophys. Union Trans., v. 65, no. 3, p. 1053-1062. 1960, Land subsidence in the Arvin-Maricopa area of the San Joaquin Valley, California, 1957-59: U.S. Geol. Survey open-file map, scale $1: 125,000$.

20 Lofgren, B. E., and Klausing, R. L., 1960, Land subsidence in the TulareWasco area, California, 1957-59: U.S. Geol. Survey open-file map, scale $1: 125,000$.

Meade, R. H., Jr., 1960, Compaction and development of preferred orientation in clayey sediments: U.S. Geol. Survey typewritten rept., 67 p., 14 figs.

17 Miller, R. E., 1961, Land subsidence in the Los Banos-Kettleman City area, 1957-59: U.S. Geol. Survey open-file map, scale 1:250,000.

Morris, D. A., and Johnson, A. I., 1959, Correlation of Atterberg limits with geology of deep cores from subsidence areas in California: Am. Soc. Testing Materials, Special Tech. Publ., no. 254, p. 183-187.

Poland, J. F., 1959, Land subsidence due to ground-water development in California: Am. Soc. Civil Engineers Proc., Jour. Irr. and Dr. Div., v. 84, no. IR3, Sept., 11 p.

17,20 Poland, J. F., and Davis, G. H., 1956, Subsidence of the land surface in the Tulare-Wasco (Delano) and Los Banos-Kettleman City area, San Joaquin Vailey, California: Am. Geophys. Ünicn Trans., v. 37, no. 3, $10 \mathrm{p}$. 
no.

17,20 Poland, J. F., and Davis, G. H., 1958, Ground-water extraction and landsubsidence problem--San Joaquin Valley, Cllif.: U.S. Geol. Survey dupl. rept., $7 \mathrm{p}$.

58 Poland, J. F., and Green, J. H., 1960, Subsidence in the Santa Clara Valley, California--A progress report: U.S. Geol. Survey typewritten rept., 13 p., 12 figs. (in preparation as a water-supply paper).

Reports in preparation

Western Fresno County geomorphology of alluvial fans.

Los Banos-Kettleman City area surface geology.

Los Banos-Kettleman City area subsurface geology.

Los Banos-Kettleman City area physical and hydrologic properties.

Los Banos-Kettleman City area land subsidence.

Western Fresno County deposition and compaction.

Tulare-Wasco area land subsidence. 
Santa Barbara County

Map

no.

21-25 Evenson, R. E., 1958, Water levels in observation wells in Santa Barbara County, California, in 1957: U.S. Geol. Survey dupl. rept., prepared in cooperation with Santa Barbara County, $46 \mathrm{p}$.

53 1961, Availability of ground water, Point Pedernales area, Calif.: U.S. Geol. Survey typewritten rept., prepared at the request of the Department of the Navy, $47 \mathrm{p}$.

53 1961, Ground-water conditions, Naval Missile Facility, Point Arguello, Calif., 1960-61: U.S. Geol. Survey typewritten rept., prepared at the request of the Department of the Navy, p.

53 Evenson, R. E., and Miller, G. A., 1960, Geology and ground-water features of Point Arguello Facility, Santa Barbara County, Calif.: U.S. Geol. Survey dupl. rept., prepared at the request of Department of the Navy, $74 \mathrm{p}$. (in preparation as a water-supply paper).

2l-25 LaRocque, G. A., Jr., and others, 1950, Wells and water levels in principal ground-water basins in Santa Barbara County, Calif.: U.S. Geol. Survey Water-Supply Paper 1068, prepared in cooperation with Santa Barbara County, 459 p.

21-25 Merritt, P. M., 1961, Water levels in observation wells in Santa Barbara County, California in 1960: U.S. Geol. Survey dupl. rept., prepared in cooperation with Santa Barbara County Water Agency, $51 \mathrm{p}$.

21-25 Miller, G. A., 1959, Water levels in observation wells in Santa Barbara County, California, in 1958: U.S. Geol. Survey dupl. rept., prepared in cooperation with Santa Barbara County, $47 \mathrm{p}$.

62 Miller, G. A., and Evenson, R. E., 1961, Geologic reconnaissance and test-well drilling at proposed Air Force Facility near Lompoc, Calif.: U.S. Geol. Survey typewritten rept., prepared at the request of the Department of the Air Force, 18 p., 2 figs.

21-25 Muir, K. S., and Merritt, P. M., 1956, Water levels in observation wells in Santa Barbura County, California, in 1955: U.S. Geol. Survey dupl. rept., prepared in cooperation with Santa Barbar. County, 69 p.

21-25 1957, Water levels in observation wells in Santa Barbara County, California, in 1956: U.S. Geol. Survey dupl. rept., prepared in cooperation with Santa Barbara County, E3 F.

21-25 Muir, K. S., Merritt, P. M., and Miller, G. A., 1960, Water levels in observation wells in Santa Barbara County, Cal ifornia, in 1959: U.S. Geol. Survey dupl. rept., prepared in cooperation with Santa Barbara County Water Agency, $46 \mathrm{p}$. 
24 Troxell, H. C., and Wilson, H. D., Jr., 1952, Reports on stream runoff and ground-water storage capacity, Santa Ynez River, Santa Barbara County, Calif.: U.S. Geol. Survey dupl. rept., prepared in cooperation with Santa Barbara County and the U.S. Bureau of Reclamation, $157 \mathrm{p}$.

24 Upson, J. E., Thomasson, H. G., Jr., and others, 1951, Geology and water resources of the Santa Ynez River valley, Santa Barbara County, Calif.: U.S. Geol. Survey Water-Supply Paper 1107, prepared in cooperation with Santa Barbara County, 194 p.

25 Upson, J. E., and others, 1951, Geology and ground-water resources of the south-coast basins of Santa Barbara county, Calif.: U.S. Geol. Survey Water-Supply Paper 1108, prepared in cooperation with Santa Barbara County, 144 p.

21 Upson, J. E., and Worts, G. F., Jr., 1951, Ground water in the Cuyama Valley, Calif.: U.S. Geol. Survey Water-Supply Paper 1110-B, prepared in cooperation with Santa Barbara County, $81 \mathrm{p}$.

21-25 U.S. Geological Survey water-supply papers giving water levels in Observation wells in Santa Barbara County: Water-Supply Paper 941 contains measurements for 1941; 949 for 1942; 991 for 1943; 1021 for 1944; 1028 for 1945; 1076 for 1946; 1101 for 1947;

1131 for 1948; 1161 for 1949; 1170 for 1950; 1196 for 1951; 1226 for 1952; 1270 for 1953; 1326 for 1954; 1409 for 1955; 1956 (in preparation); 1957 (in preparation); 1958 (in preparation); 1959 (in preparation); 1960 (in preparation); 1961 (data available).

24 Wilson, H. D., Jr., 1959, Ground-water appraisal of the Santa Ynez River basin, Santa Barbara County, Calif., 1945-52: U.S. Geol. Survey Water-Supply Paper 1467, prepared in cooperation with the U.S. Bureau of Reclamation and the Santa Barbara County Water Agency, $119 \mathrm{p}$.

Worts, G. F., Jr., 1951, Geology and ground-water resources of the Santa Maria Valley area, Santa Barbara County, Calif.: U.S. Geol. Survey Water-Supply Paper 1000, prepared in cooperation with Santa Barbara County, $169 \mathrm{p}$.

25 Carpenteria and Goleta basins reappraisal, Santa Barbara County (report in preparation)

23 San Antonio Valley (report in preparation) 
Southern California:

Area South of the Tehachapi Mountains and Desert Areas

Map

no.

Bader, J. S., Kunkel, Fred, 1957, A brief memorandum on the water supply at five Forest Service guard stations, Cleveland National Forest, San Diego County, California: U.S. Geol. Survey dupl. rept., prepared at the request of the Department of Agriculture, U.S. Forest Service, $17 \mathrm{p}$.

46 Bader, J. S., and Moyle, W. R., Jr., 1958, Data on water wells and springs in Morongo Valley and vicinity, San Bernardino and Riverside Counties, California: U.S. Geol. Survey duplicated report, prepared in cooperation with the California Department of Water Resources, $31 \mathrm{p}$.

1960, Data on water wells and springs in Yucca Valley-Twentynine Palms area, San Bernardino and Riverside Counties, Calif.: California Department of Water Resources Bull. 9l-2, $163 \mathrm{p}$.

33a Bader, J. S., Page, R. W., and Dutcher, L. C., 1958, Data on water wells in the Upper Mojave Valley area, San Bernardino County, Calif.: U.S. Geol. Survey duplicated report, prepared in cooperation with the California Department of Water Resources, $238 \mathrm{p}$.

43 Burnham, W. L., 1954, Data on water wells in Borrego, Octillo, San Felipe, and Vallecito Valley areas, eastern San Diego County, Calif.: U.S. Geol. Survey dupl. rept., prepared in cooperation with the California Department of Water Resources, 60 p.

1.955, Data on water wells in Coyote, Cronise, Soda, and Silver Lake valleys, San Bernardino County, Calif.: U.S. Geol. Survey dupl. rept., prepared in cooperation with the California Department of Water Resources, $43 \mathrm{p}$.

40 Burnham, W. L., and Dutcher, L. C., 1956, Map of Rediands-Beaumont area, California, showing well locations and water-level contours for March 1955: U.S. Geol. Survey duplicated sheet, prepared in cooperation with San Bernardino County Flood Control District, I pl.

401960 , Geology and ground-water hydrology of the Redlands-Beaumont area, California, with special reference to ground-water cutflow: U.S. Geol. Survey typewritten report, prepared in cooperation with the San Bernardino County Flood Control District, 331 p. (in preparation as a water-supply paper).

$6 C$ Burnham, W. L., and Kunkel, Fred, 1960, Geologic and hydrologic reconnaissance of San Nicolas Island, California: U.S. Geol. Survey typewritten rept., prepared at the request of the Department of the Navy, $42 \mathrm{p}$. (in preparation as a water-supply paper). 
Dutcher, L. C., 1955, Possibilities for developing productive water wells at the Veterans Administration Hospital, Sepulveda, Calif.: U.S. Geol. Survey typewritten memorandum report, prepared at the request of the Veterans Administration, Washington, D. C., 16 p. 1956, Memorandum summarizing preliminary estimates of ground-water outflow from Bunker Hill Basin at Colton Narrows, San Bernardino County, Calif.: U.S. Geol. Survey dupl. rept., prepared in cooperation with the San Bernardino County Flood Control District, $14 \mathrm{p}$.

1959, Data on water wells in the Fremont Valley area, Kern County, California: U.S. Geol. Survey dupl. rept., prepared in cooperation with the California Department of Water Resources, $128 \mathrm{p}$.

1959, Ground-water Inventory for 1958, Edwards Air Force Base, California: U.S. Geol. Survey typewritten report, prepared at the request of the Department of the Air Far ce, p. 1960, Ground-water conditions during 1959 at the Marine Corps Base, Twentynine Palms, California: U.S. Geol. Survey typewritten rept., prepared at the request of the Department of the Navy, $26 \mathrm{p}$.

54 Dutcher, L. C., and Bader, J. S., 1960, Geology and hydrology of Agua Caliente Spring, Palm Springs, Calif.: U.S. Geol. Survey typewritten rept., prepared at the request of the Bureau of Indian Affairs, (in preparation as a water-supply paper).

41 Dutcher, L. C., and Burnham, W. L., 1959, Geology and ground-water hydrology of the Mill Creek area, San Bernardino County, California: U.S. Geol. Survey dupl. rept., prepared in cooperation with the city of Redlands, $229 \mathrm{p}$. (in preparation as a water-supply paper).

39 Dutcher, L. C., and Garrett, A. A., 1958, Geologic and hydrologic features of the San Bernardino area, Calif., with special reference to the underflow across the San Jacinto fault: U.S. Geol. Survey dupl. rept., prepared in cooperation with the San Bernardino County Flood Control District, 215 p. (in preparation as a water-supply paper).

55 Dutcher, L. C., and Hiltgen, W. J., 1954, Appendix B. Tables of basic data for areas outside Edwards Air Force Base, California: U.S. Geol. Survey dupl. rept., prepared at the request of the Department of the Air Force, $115 \mathrm{p}$. Force Base, California: U.S. Geol. Survey dupl. rept., prepared at the request of the Department of the Air Force, $84 \mathrm{p}$. 
55 Dutcher, L. C., and Worts, G. F., Jr., 1958, Geology and ground-water appraisal of Edwards Air Force Base and vicinity, California: U.S. Geol. Survey typewritten rept., prepared at the request of the Department of the Air Force, $229 \mathrm{p}$.

48 Dyer, H. B., 1961, Ground-water conditions during 1960 at the Marine Corps Base, Twentynine Palms, Calif.: U.S. Geol. Survey typewritten rept., prepared at the request of the Department of the Navy, $32 \mathrm{p}$.

37 Garrett, A. A., 1949, Status of salt-water contamination in the coastal part of Orange County, Calif., as of 1949: U.S. Geol. Survey dupl. rept., prepared in cooperation with the orange County Flood Control District and Orange County Water District, $36 \mathrm{p}$. Similar reports prepared, released, and duplicated for 1950, 1951, 1952.

39 Garrett, A. A., and Dutcher, L. C., 1953, San Bernardino area, Calif.; three maps showing water-level contours for spring 1936, spring 1945, and spring 1951; east-west section from Colton to Mill Creek Canyon, geologic section from Shandin Hills southeast to Bryn Mawr; and water-level profiles along the section from Colton to Mill creek Canyon: U.S. Geol. Survey dupl. sheets, prepared in cooperation with San Bernardino County Flood Control District, 6 pls.

1954, Tables of basic data for the San Bernardino area, Calif.: U.S. Geol. Survey dupl. rept., prepared in cooperation with the San Bernardino County Flood Control District, $170 \mathrm{p}$.

Garrett, A. A., and Thomasson, H. G., Jr., 19/9, Ground-water outflow from Chino Basin, Calif., and the controling geologic and hydrologic conditions: U.S. Geol. Survey dupl. rept., prepared in cooperation with the San Bernardino County Flood Control District, $143 \mathrm{p}$.

Kunkel, Fred, 1956, Data on water wells in Cuddeback, Superior, and Harper Valleys, San Bernardino County, Calif.: U.S. Geol. Survey dupl. rept., prepared in cooperation with the California Department of Water Resources, $73 \mathrm{p}$. 1956, A brief hydrologic and geologic reconnaissance of Pinto Basin, Joshua Tree National Monument, Riverside County, Calif.: U.S. Geol. Survey dupl. rept., prepared at the request of the National Park Service, $35 \mathrm{p}$. (in preparation as a water-supply paper).

1960, Ground water in western part of Mojave Desert region, California: U.S. Geol. Survey Hydrologic Atlas, HA-3l.

27 Kunkel, Fred, and others, 1960, Data on water wells in the Willow Springs, Gloster, and Chaffee areas, Kern County, Cal if.: California Department of Water Resources Bull. 91-4, 85 p.

42 Kunkel, Fred, 1960, Summary of hydrologic conditions at Joshua Tree National Monument, Riverside County, Calif., 1956-59: U.S. Geol. Survey dupl. rept., prepared at the request of the National Park Service, $18 \mathrm{p}$. 
26 Kunkel, Fred, Chase, G. H., and Hiltgen, W. J., 1955, Takles of basic data on geology and ground water of the Inyokern Naval Ordnance Test Station and vicinity, California: U.S. Geol. Survey dupl. rept., prepared at the request of the Department of the Navy, $115 \mathrm{p}$.

31 Kunkel, Fred, and Riley, F. S., 1959, Geologic reconnaissance and test-well drilling at Camp Irwin, Calif.: U.S. Geol. Survey Water-Supply Paper 1460-F, prepared in cooperation with the U.S. Army Corps of Engineers, p. 233-271.

55 Moyle, W. R., Jr., 1960, Ground-water inventory for 1959, Edwards Air Force Base, California: U.S. Geol. Survey typewritten rept., prepared at the request of the Department of the Air Force, p.

1961, Ground-water inventory for 1960, Edwards Air Force Base, California: U.S. Geol. Survey typewritten rept., prepared at the request of the Department of the Air Force, p. 1961, Data on water wells in Dale Valley area, San Bernardino and Riverside Counties, California: California Department of Water Resources Bull. 91-5, 55 p.

Moyle, W. R., Jr., and Kunkel, Fred, 1960, Ground-water conditions during 1959 in Indian Wells Valley, California: U.S. Geol. Survey typewritten rept., $27 \mathrm{p}$.

44 Olmsted, F. H., 1953, Geologic features and water resources of Campo, Mesa Grande, La Jolla, and Pauma Indian Reservations, San Diego County, Calif.: U.S. Geol. Survey dupl. rept., prepared at the request of the U.S. Bureau of Indian Affairs, $129 \mathrm{p}$.

45 1956, Geologic reconnaissance of San clemente Island, Calif.: U.S. Geol. Survey Bull. 1071-B.

59 Page, R. W., 1961, Ground-water conditions during 1959 at the Naval Air Missile Test Center area, Point Mugu, California: U.S. Geol. Survey typewritten rept., prepared at the request of the Department of the Navy, $32 \mathrm{p}$.

1961, Geology and ground-water appraisal of the Naval Air Missile Test Center area, Pt. Mugu, Calif.: U.S. Geol. Survey typewritten rept., prepared at the request of the Department of the Navy, $85 \mathrm{p}$.

1961, Test-well drilling, San Nicolas Island, Calif.: U.S. Geol. Survey typewritten rept., prepared in cooperation with the Department of the Navy, $26 \mathrm{p}$; to be summarized as an appendix to the report "Geologic and hydrologic reconnaissance of San Nicolas Island, California," by W. L. Burnham and Fred Kunkel. 
59 Page, R. W., and Kunkel, Fred, 1960, Data on water wells, Naval Air Missile Test Center area, Point Mugu, California: U.S. Geol. Survey dupl. rept., prepared at the request of the Navy, $98 \mathrm{p}$.

33c Page, R. W., and Moyle, W. R., Jr., 1960, Data on water wells in the eastern part of the middle Mojave Valley area, San Bernardino County, California: California Department of Water Resources Bull. 91-3, $223 \mathrm{p}$.

33b Page, R. W., Moyle, W. R., Jr., and Dutcher, L. C., 1960, Data on wells in the west part of the Middle Mojave Valley area, San Bernardino County, California: California Department of Water Resources Bull. $91-1,126 \mathrm{p}$.

37 Piper, A. M., Garrett, A. A., and others, 1953, Native and contaminated ground waters in the Long Beach-Santa Ana area, Calif.: U.S. Geol. Survey Water-Supply Paper 1136, prepared in cooperation with the Orange County Flood Control District, Orange County Water District, Los Angeles County Flood Control District, and Board of Water Commissioners of City of Long Beach, $320 \mathrm{p}$.

37 Piper, A. M., Poland, J. F., and others, 1942, Index of factual data from water wells on a part of the coastal plain in Los Angeles and Orange Counties, Calif.: U.S. Geol. Survey dupl. rept., prepared in cooperation with Orange County Flood Control District, Orange County Water District, Los Aisgeles County Flood Control District, and Board of Water Commissioners of City of Long Beach, $298 \mathrm{p}$.

Piper, A. M., and Poland, J. F., 1945, Ground water for emergency public supply at San Diego, Calif.: U.S. Geol. Survey typewritten rept., prepared at the request of the War Production Board, $29 \mathrm{p}$.

47 Pistrang, M. A., and Kunkel, Fred, 1958, A brief geologic and hydrologic reconnaissance of the Furnace Creek Wash area, Death Valley National Monument, Calif.: U.S. Geol. Survey duplicated report, prepared at the request of the National Park Service, $63 \mathrm{p}$. (in preparation as a water-supply paper).

37 Poland, J. F., 1947, sumnary statement of ground-water conditions and saline contamination along the coast of orange County, Calif.: Orange County Water District dupl. rept., prepared in cooperation with the U.S. Geol. Survey, 20 p.

35 Poland, J. F., Garrett, A. A., and Sinnott, Allen, 1959, Geology, hydrology, and chemical character of the ground waters in the Torrance-Santa Monica area, Los Angeles County, Calif.: U.S. Geol. Survey Water-Supply Paper 1461, prepared in cooperation with the Los Angeles County Flood Control District and local municipalities, $425 \mathrm{p}$. 
37 Poland, J. F., and Piper, A. M., and others, 1956, Ground-water geology of the coastal zone, Long Beach-Santa Ana area, Calif.: U. S. Geol. Survey Water-Supply Paper 1109, prepared in cooperation with the Orange County Flood Control District, Orange County Water District, Los Angeles County Flood Control District, and Board of Water Commissioners of City of Long Beach, 162 p.

37 Poland, J. F., and others, 1959, Hydrology of the Long Beach-Santa Ana area, Calif.: U.S. Geol. Survey Water-Supply Paper 1471, prepared in cooperation with the Orange County Flood Control District, Orange County Water District, Los Angeles County Flood Control District, and Board of Water Commissioners of City of Long Beach, $257 \mathrm{p}$.

34 Riley, F. S., 1956, Data on water wells in Lucerne, Johnson, Fry, and Means Valleys, San Bernardino County, Calif.: U.S. Geol. Survey dupl. rept., prepared in cooperation with the California Department of Water Resources, $150 \mathrm{p}$.

48 Riley, F. S., and Bacier, J. S., 1961, Data on water wells on Marine Corps Base, Twentynine Palms, Calif.: U.S. Geol. Survey dupl. rept., prepared at the request of the Department of Navy, p.

Troxell, H. C., Poland, J. F., and others, 1951, Some espects of the water supply in the South Coastal Basin, Calif.: U.S. Geol. Survey Circular 105, $10 \mathrm{p}$.

Worts, G. F., Jr., 1958, Report on the Pauba Ranch exploratory well, Riverside County, Calif.: U.S. Geol. Survey typewritten rept., prepared in cooperation with the Department of the Navy, p. 


\section{California: General}

Davis, G. H., Worts, G. F., Jr., and Wilson, H. D., Jr., 1955, Water-level fluctuations in wells, in Earthquakes in Kern County, Calif.: California Division of Mines Bull. 171, Part I, no. 10, p. 99-106.

Johnson, A. I., Prill, R. C., and Morris, D. A., 1961, Specific yield-Column drainage and centrifuge moisture content: U.S. Geol. Survey dupl. rept., prepared in cooperation with the California Department of Water Resources, 117 p., 36 figs. (in preparation as a watersupply paper).

Johnson, A. I., Morris, D. A., and Prill, R. C., 1961, Specific yield and related properties an annotated bibliography: U.S. Geol. Survey dupl. rept., prepared in cooperation with the California Department of Water Resources, $245 \mathrm{p}$.

Poland, J. F., 1950, Ground water in Cal1fornia: Am. Inst. Mining Engineers Trans., v. 187, p. 279-284.

U.S. Geological Survey Water-Supply Papers giving information on water levels and artesian pressure in observation wells in California: U.S. Geol. Survey Water-Supply Paper 468 contains measurements for 1920 and prior years; 777 for 1935; 817 for 1936; 840 for 1937; 845 for 1938; 886 for 1939; 911 for 1940; 941 for 1941; 949 for 1942 (principal records for Long Beach-Santa Ana area); 991 for 1943; 1021 for 1944; 1028 for 1945 (principal records for TorranceSanta Monica area); 1076 for 1946; 1101 for 1947; 1131 for 1948; 1161 for 1949; 1170 for 1950; 1196 for 1951; 1226 for 1952; 1270 for 1953; 1326 for 1954; 1409 for 1955; 1956 (in preparation); 1957 (in preparation); 1958 (in preparation); 1959 (in preparation); 1960 (in preparation); 1961 (data available). 


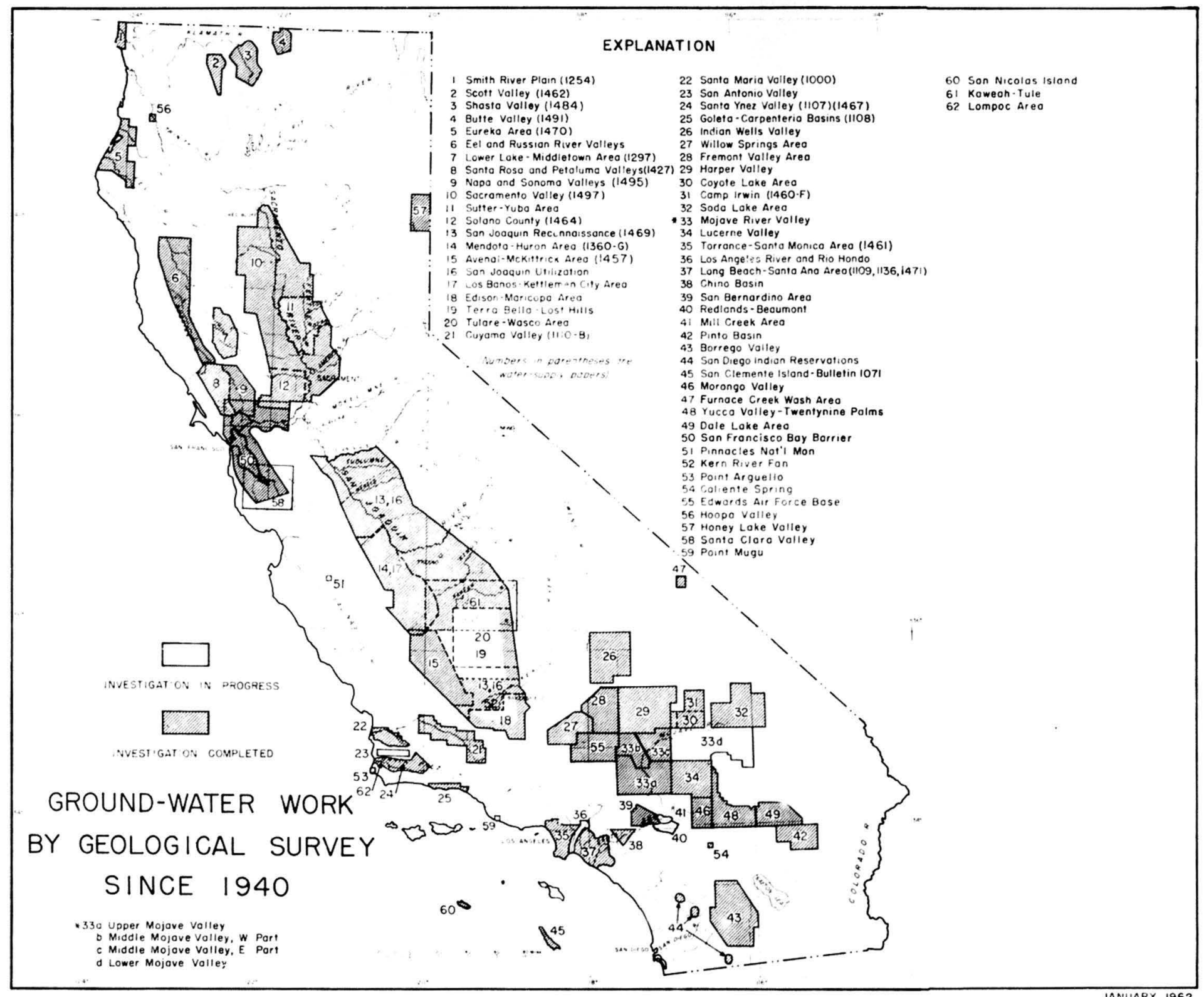

